\title{
Association of Blood and Urine Parameter Value Change With the Amount of Consumed Water Regime and Sample Sampling in Healthy Individuals
}

Snezana M Jovicic ( $\sim$ sneza90bg@hotmail.com )

Department of Genetics, Faculty of Biology, University of Belgrade

Research

Keywords: preanalytical factors, water intake, sample sampling, blood biomarkers, urine biomarkers, healthy participants

Posted Date: March 1st, 2021

DOI: https://doi.org/10.21203/rs.3.rs-258592/v1

License: (ㅇ (i) This work is licensed under a Creative Commons Attribution 4.0 International License.

Read Full License 


\section{Abstract}

Background: Understanding the effect of pre-analytical factors is important for data quality of biospecimens and health status. The study examines the effect of 9-days fluid intake and 2-time sampling on concentration changes of 7-Urine and 17-Blood variables.

Material and Method: SPSS software v23.0 applies to data processing. The group of 23 healthy subjects divide based on water intake and gender.

Results: A statistically significant difference $(p<0.01)$ between $1^{\text {st }} / 2^{\text {nd }}$ sampling is confirmed for Freezing point depression, Sodium, Potassium, Creatinine Urea and Urate in Urine and Urea, Urate, Glucose, Hematocrit, Thrombocyte in Blood. The difference between water intake after $1^{\text {st }}$ sampling is confirmed $(p<0.01)$ for Freezing point depression, Sodium, Urate and $(p<0.05)$ for Potassium $(p<0.05)$, Chloride $(p<0.05)$, Creatinine $(p<0.05)$, Urate, Urea in Urine and Potassium $(p<0.01)$ and Chloride $(p<0.05)$ in Blood. Difference between gender exists for Urea $(p<0.05)$ in Urine after $2^{\text {nd }}$ sampling and Urate $(P<0.01)$, Glucose $(\mathrm{p}<0.01 / 0.05), \mathrm{Ht}(\mathrm{p}<0.01 / 0.05)$ after $1^{\text {st }}$ and $2^{\text {nd }}$ sampling and $\mathrm{MCHC}(\mathrm{p}<0.01)$ after $2^{\text {nd }}$ sampling in Blood samples.

Conclusion: Water intake increases blood and urine biomarker range after sampling.

\section{Background}

Sustainable effort must obtain for sensitivity, specificity, robustness and reproducibility of data. Preanalytical factors influence sample quality; reproducibility, stability and false-positive results. [1, 2]. Preanalytic variables include 3. categories, physiologic (age, gender, sex, time, season, altitude, menstruation, pregnancy, lifestyle like diet, caffeine, ethanol, smoking), specimens collection (overnight fasting, time of specimen collection, posture during sampling, exercise, water intake, anticoagulants-blood ratio, specimen handling and processing, added additives with anticoagulants), and influence or interference factors (drug metabolites, laboratory tests, collection tube) affecting variable range [3].

Nervous system maintains organism homeostasis in the inward environment answering to external stimulus $[4,5]$. Water intake as pre-analytical variable contributes to biochemical processes and affects establishing reference range, disease diagnosis, prognosis and follow-up [6, 7]. Urine and Blood samples are the most commonly used in clinical practice reflecting state of metabolome and metabolic end product $[6,7]$. Critical aspects of biomarker stability during clinical planning, sample collection, training, selection of sample preservation, buffers, shipping, logistics, method analysis and results in the presentation is known for the most utilized bio-specimens [8]. Studies analyzed conditions like storage time, temperature, freezing-thawing cycle on biomarker range and reproducibility [1-3]. Despite increasing sensitivity of methodology for determining biomarker range, discrepancies among variables exist in the literature due to sampling frequency, sample and pre-analytical factor interaction complexity 
[9]. Fluid intake habits and the effect on Urine/Blood biomarkers of healthy participants lack in the literature.

A current study was done as a part of the $\mathrm{PhD}$ thesis aim to examine the effect of 7 and 9-day regime water intake in Test (T) and Control (C) group on 7-Blood (Freezing point depression_FPD, Potassium_K', Sodium_Na ${ }^{+}$, Chloride_Cl ${ }^{-}$, Urea, Creatinine_Cr, Urate) and 17-Urine (Urea, $\mathrm{Cr}$, Urat, Glucose_Glu, C reactive protein_CRP, Leucocyte_LE, Erythrocyte_ER, Hemoglobine_Hg, Hematocrit_Ht, Mean Corpuscular Volume_MCV, Mean Corpuscular Hemoglobin_MCH, Mean Corpuscular Hemoglobin Concentration_MCHC, MPV_Mean Platelet Volume, Trombocyte_TR, $\mathrm{K}^{+}, \mathrm{Na}^{+}, \mathrm{Cl}^{-}$) parameters in healthy subjects, during 2 sample collection, depending on gender and water intake level. Hypothesis postulate that water intake affects the reference range of Urine and Blood biomarkers.

\section{Material And Methods}

\section{Human biological material dataset}

Experiments were performed according to ethical standards and with the written consent of the blood donors. Permission from the National Medical Ethics Committee, number 82/07/14, is given.

Participants differ by Gender (Male_M;Female_F), the amount of drinking water, Blood and Urine parameter values. A total number of participants consist of 23 . healthy participants $(F=9, M=14) . M$ $(60.9 \%)$ were numerous in comparing to $F(39.1 \%)$ participants. Mean water intake for 5 . days, is recorded. An upward trend in the T group and downward in the $\mathrm{C}$ group exists. The T group drank more than $1800 \mathrm{ml}$ with a mean water intake value of $2055 \mathrm{ml}$. The $\mathrm{C}$ group consumed less than $2000 \mathrm{ml}$, with a mean water intake value of $1846 \mathrm{ml}$. The number of M/F participants in T/C group varies. The 14 subjects in the T group [M:(9/23); F:(5/23)] represent $39.12 \% \mathrm{M}$ and $21.74 \% \mathrm{~F}$ of the total participant. Meanwhile, 9 subjects in the C group [M:(5/23); F:(4/23)] represent $21.74 \% \mathrm{M}$ and $17.4 \% \mathrm{~F}$-number of the total participant.

The regime of water intake for 23 healthy subjects included 5-days of controlled water consumption, 2days of arbitrary higher water intake in T group before $1 \mathrm{st}$ sampling (7th -day of water intake), 2-days of desired lover water intake in T group before 2nd sampling (9th -day of water intake), while C group drank the same level of water during 1 st and 2nd sampling. Of the total M/F participants, 7-Urine and 14 Blood (Urea, Creatinine, Urate, Glucose, CRP, LE, ER, Hg, Ht, MCV, MCH, MCHC, MPV, TR) variables tested for a change. On 11 male participants, 3 additional electrolytes $\left(\mathrm{Na}^{+}, \mathrm{K}^{+}, \mathrm{CL}^{-}\right)$test for a change.

\section{Statistical analysis}

IBM-SPSS software v23.0 applies for statistical data analysis. Descriptive statistics, Shapiro-Wilk normality test, parametric and non-parametric statistical tests such as Paired and Independent T-test, Wilcoxon and Mann-Whitney/Kruskal-Wallis test is employed. Results display mean (SD) and p-value. A statistically significant correlation was assumed when $\mathrm{P}<0.05$. 


\section{Results And Discussion}

Urine and Blood characteristics are present in Table 1 and Table 2. Shapiro-Wilk test indicated the presence of normality $(P>0.05)$ for $\mathrm{FPD}, \mathrm{K}^{+}, \mathrm{Na}^{+}, \mathrm{Cl}^{-}, \mathrm{Cr}$ and Urate during 2nd sampling and Urea during 1st sampling in Urine samples and for Glucose, MPV during 2nd sampling, Urea, Urate, Ht, MPV during 1st sampling and $\mathrm{K}^{+}$during $1 \mathrm{st}$ and $2 \mathrm{nd}$ sampling in blood samples. All other variables showed an absence of normality $(P<0.05)$. All non-parametric data transform to normality using log transformation, except for CRP and additional electrolytes in the Blood. Based on this notion, the parametric and non-parametric test is employed. 
Table 1

Urine parameter value during 1 st and 2 nd sampling

Table 1. Participant Urine parameter
Participants group

Control

Mean Standard
Test

Mean

Deviation

Freezing point depression (mK)_1st

sampling

Freezing point depression (mK)_2nd
sampling

$\mathrm{K}$ (mmol/L)_1st sampling

$\mathrm{K}$ (mmol/L)_2nd sampling

$\mathrm{Na}$ (mmol/L)_1st sampling

$\mathrm{Na}$ (mmol/L)_2nd sampling

$\mathrm{Cl}$ (mmol/L)_1st sampling

$\mathrm{Cl}$ (mmol/L)_2nd sampling

Urea (mmol/L)_1st sampling

Urea (mmol/L)_2nd sampling

$\mathrm{Cr}$ (mmol/L)_1st sampling

$\mathrm{Cr}$ (mmol/L)_2nd sampling

$\begin{array}{lll}\text { Female } & 852.75 & 591.82 \\ \text { Male } & 1072.00 & 455.10\end{array}$

Female $\quad 37.50 \quad 19.23$

27.40

Male

59.20

28.58

17.56

Female $\quad 23.75 \quad 8.46$

38.20

Male

51.40

19.45

39.00

Female 82.25

Male

99.80

65.51

38.40

Female 103.50

48.02

23.89

Male

101.00

57.74

68.00

Female $\quad 77.50$

61.56

84.56

Male $\quad 140.80 \quad 73.65$

49.40

33.56

Female $\quad 82.25 \quad 50.41$

52.20

Male

115.60

77.35

78.89

\section{Fem}

Ma

Female

188.50

145.42

111.40

Fe

Female

210.80

85.51

80.11

Male $\quad 212.00 \quad 70.25$

216.00

$\begin{array}{lll}\text { Female } & 13.08 & 13.4 \\ \text { Male } & 12.06 & 9.09\end{array}$

Female

13.43

1.63

9.68

$479.40 \quad 240.33$

$334.44 \quad 103.97$

$858.40 \quad 380.45$

$1283.44 \quad 579.44$

Male $\quad 1000.20 \quad 362.34 \quad 1283.44 \quad 579.44$

13.72

9.61

18.09

17.20

15.42

8.67

25.09

47.67

18.69

13.00

19.92

61.76

70.96

44.90

126.16

8.25

Male

8.88

370.22

188.24

$4.26 \quad 4.23$

5.54

$\begin{array}{lll}4.40 & 15.07 & 8.59\end{array}$




\begin{tabular}{|llllll|} 
Urat (mmol/L)_1st sampling & Female & 2.18 & 1.71 & 0.96 & 0.55 \\
\cline { 2 - 6 } & Male & 2.02 & 0.86 & 0.78 & 0.32 \\
\hline \multirow{2}{*}{ Urat (mmol/L)_2nd sampling } & Female & 1.78 & 0.75 & 1.74 & 0.78 \\
& Male & 1.82 & 0.53 & 2.74 & 1.24 \\
\hline
\end{tabular}


Table 2

Blood parameter value during 1 st and 2 nd sampling

\begin{tabular}{|c|c|c|c|c|c|}
\hline \multicolumn{2}{|c|}{ Table 2. Participant blood parameter } & \multicolumn{4}{|c|}{ Participants group } \\
\hline & & \multicolumn{2}{|l|}{ Control } & \multicolumn{2}{|l|}{ Test } \\
\hline & & Mean & $\begin{array}{l}\text { Standard } \\
\text { Deviation }\end{array}$ & Mean & $\begin{array}{l}\text { Standard } \\
\text { Deviation }\end{array}$ \\
\hline \multirow[t]{2}{*}{ Urea (mmolL)_1st sampling } & Female & 3.65 & 1.68 & 3.74 & 0.86 \\
\hline & Male & 4.26 & 1.40 & 3.77 & 1.13 \\
\hline \multirow[t]{2}{*}{ Urea (mmolL)_2nd sampling } & Female & 3.60 & 0.82 & 3.82 & 0.68 \\
\hline & Male & 4.32 & 1.43 & 4.51 & 1.67 \\
\hline \multirow[t]{2}{*}{ Cr ( $\mu$ molL)_1st sampling } & Female & 72.25 & 9.54 & 61.80 & 4.60 \\
\hline & Male & 67.00 & 6.08 & 72.44 & 10.50 \\
\hline \multirow[t]{2}{*}{$\mathrm{Cr}$ ( $\mu \mathrm{molL}) \_2$ nd sampling } & Female & 71.25 & 7.85 & 63.80 & 4.38 \\
\hline & Male & 64.80 & 5.45 & 74.11 & 10.40 \\
\hline \multirow[t]{2}{*}{ Urat ( $\mu$ molL)_1st sampling } & Female & 245.50 & 18.63 & 263.60 & 32.53 \\
\hline & Male & 329.80 & 38.23 & 280.00 & 21.17 \\
\hline \multirow[t]{2}{*}{ Urat ( $\mu$ molL)_2nd sampling } & Female & 259.00 & 14.70 & 287.20 & 20.19 \\
\hline & Male & 332.20 & 58.98 & 310.22 & 42.42 \\
\hline \multirow{2}{*}{$\begin{array}{l}\text { Glucose (mmolL)_1st } \\
\text { sampling }\end{array}$} & Female & 4.05 & 0.26 & 4.20 & 0.16 \\
\hline & Male & 4.84 & 0.79 & 4.62 & 0.48 \\
\hline \multirow{2}{*}{$\begin{array}{l}\text { Glucose (mmolL)_2nd } \\
\text { sampling }\end{array}$} & Female & 4.25 & 0.24 & 4.46 & 0.30 \\
\hline & Male & 4.92 & 0.57 & 4.67 & 0.45 \\
\hline \multirow[t]{2}{*}{ CRP (mg/L)_1st sampling } & Female & 1.00 & 0.00 & 0.80 & 0.84 \\
\hline & Male & 2.80 & 2.59 & 0.67 & 0.50 \\
\hline \multirow[t]{2}{*}{ CRP (mg/L)_2nd sampling } & Female & 1 & 1 & 1 & 2 \\
\hline & Male & 3 & 3 & 1 & 1 \\
\hline \multirow[t]{2}{*}{ LE (109/L)_1st sampling } & Female & 6.45 & 0.62 & 6.00 & 0.97 \\
\hline & Male & 5.86 & 1.71 & 6.86 & 1.70 \\
\hline \multirow[t]{2}{*}{ LE (10\%/L)_2nd sampling } & Female & 6.8 & 1.1 & 6.6 & 2.1 \\
\hline & Male & 6.0 & 1.4 & 6.6 & 1.3 \\
\hline
\end{tabular}




\begin{tabular}{|c|c|c|c|c|c|}
\hline \multicolumn{2}{|c|}{ Table 2. Participant blood parameter } & \multicolumn{4}{|c|}{ Participants group } \\
\hline & & \multicolumn{2}{|l|}{ Control } & \multicolumn{2}{|l|}{ Test } \\
\hline & & Mean & $\begin{array}{l}\text { Standard } \\
\text { Deviation }\end{array}$ & Mean & $\begin{array}{l}\text { Standard } \\
\text { Deviation }\end{array}$ \\
\hline \multirow[t]{2}{*}{ ER (10/L)_1st sampling } & Female & 4.48 & 0.36 & 4.64 & 0.18 \\
\hline & Male & 4.90 & 0.32 & 4.80 & 0.34 \\
\hline \multirow[t]{2}{*}{ ER (109/L)_2nd sampling } & Female & 4.5 & 0.4 & 4.7 & 0.3 \\
\hline & Male & 4.9 & 0.4 & 4.8 & 0.4 \\
\hline \multirow[t]{2}{*}{$\mathrm{Hg}(\mathrm{g} / \mathrm{L})$ _1st sampling } & Female & 132.00 & 6.78 & 135.20 & 8.14 \\
\hline & Male & 144.20 & 14.97 & 141.56 & 11.06 \\
\hline \multirow[t]{2}{*}{$\mathrm{Hg}(\mathrm{g} / \mathrm{L}) \_2$ nd sampling } & Female & 130 & 8 & 138 & 9 \\
\hline & Male & 143 & 14 & 139 & 12 \\
\hline \multirow[t]{2}{*}{ Ht_1st sampling } & Female & 0.39 & 0.01 & 0.40 & 0.02 \\
\hline & Male & 0.43 & 0.04 & 0.42 & 0.03 \\
\hline \multirow[t]{2}{*}{ Ht_2nd sampling } & Female & 0.39 & 0.02 & 0.41 & 0.02 \\
\hline & Male & 0.43 & 0.03 & 0.42 & 0.03 \\
\hline \multirow[t]{2}{*}{ MCV (fl)_1st sampling } & Female & 88.25 & 6.18 & 86.80 & 3.03 \\
\hline & Male & 88.00 & 6.20 & 88.33 & 4.95 \\
\hline \multirow[t]{2}{*}{ MCV (fl)_2nd sampling } & Female & 88 & 5 & 87 & 3 \\
\hline & Male & 89 & 7 & 88 & 5 \\
\hline \multirow[t]{2}{*}{ MCH (pg)_1st sampling } & Female & 29.50 & 2.08 & 29.00 & 1.00 \\
\hline & Male & 29.60 & 2.51 & 29.56 & 2.24 \\
\hline \multirow[t]{2}{*}{ MCH (pg)_2nd sampling } & Female & 30 & 2 & 30 & 1 \\
\hline & Male & 29 & 2 & 29 & 2 \\
\hline \multirow[t]{2}{*}{ MCHC (g/L)_1st sampling } & Female & 335.00 & 8.21 & 337.20 & 6.02 \\
\hline & Male & 334.40 & 5.90 & 334.11 & 8.10 \\
\hline \multirow[t]{2}{*}{ MCHC (g/L)_2nd sampling } & Female & 333 & 9 & 341 & 5 \\
\hline & Male & 328 & 8 & 331 & 10 \\
\hline MPV (fl)_1st sampling & Female & 8.75 & .50 & 8.40 & 0.89 \\
\hline
\end{tabular}




\begin{tabular}{|c|c|c|c|c|c|}
\hline \multicolumn{2}{|c|}{ Table 2. Participant blood parameter } & \multicolumn{4}{|c|}{ Participants group } \\
\hline & & \multicolumn{2}{|l|}{ Control } & \multicolumn{2}{|l|}{ Test } \\
\hline & & Mean & $\begin{array}{l}\text { Standard } \\
\text { Deviation }\end{array}$ & Mean & $\begin{array}{l}\text { Standard } \\
\text { Deviation }\end{array}$ \\
\hline & Male & 9.00 & 1.22 & 7.78 & 0.97 \\
\hline \multirow[t]{2}{*}{ MPV (fl)_2nd sampling } & Female & 9 & 1 & 8 & 1 \\
\hline & Male & 9 & 1 & 8 & 1 \\
\hline \multirow[t]{2}{*}{ TR (109\%/L)_1st sampling } & Female & 239.75 & 26.70 & 251.60 & 51.57 \\
\hline & Male & 261.80 & 31.07 & 264.00 & 52.69 \\
\hline \multirow[t]{2}{*}{ TR (109/L)_2nd sampling } & Female & 259 & 38 & 269 & 50 \\
\hline & Male & 255 & 36 & 275 & 39 \\
\hline K (mmolL)_1st sampling & Male & 4.4 & 0.2 & 4.0 & 0.2 \\
\hline K (mmolL)_2nd sampling & Male & 4.2 & 0.2 & 4.1 & 0.2 \\
\hline $\mathrm{Na}$ ( $\mu \mathrm{molL}) \_1$ st sampling & Male & 137 & 2 & 134 & 5 \\
\hline $\mathrm{Na}$ ( $\mu$ molL)_2nd sampling & Male & 137 & 2 & 136 & 5 \\
\hline Cl ( $\mu$ molL)_1st sampling & Male & 104 & 1 & 100 & 4 \\
\hline Cl ( $\mu$ molL)_2nd sampling & Male & 102 & 1 & 101 & 4 \\
\hline
\end{tabular}

Paired T-test revealed a statistically significant difference $(P<0.01,95 \% \mathrm{Cl})$, between 1 st and 2nd sampling for FPD, $\mathrm{Na}^{+}, \mathrm{K}^{+}, \mathrm{Cr}$, Urea, Urate in Urine and Urea, Urate, Glu, $\mathrm{Ht}$, TR in Blood. Wilcoxon T-test shows the absence of statistically significant difference $(P>0.05, a=0.05,95 \% \mathrm{Cl})$ for CRP in Blood. Results are confirmed with Mann-Whitney and Kruskal-Wallis test. The difference between T/C group confirm independent T-test for FPD $(P<0.01), \mathrm{K}^{+}(P<0.05), \mathrm{Na}^{+}(P<0.01), \mathrm{Cl}^{-}(\mathrm{P}<0.05), \mathrm{Cr}(\mathrm{P}<0.05)$, Urate $(P<0.01)$ and Urea $(P<0.05)$ in Urine after 1st sampling and $\mathrm{K}^{+}(P<0.01)$ and $\mathrm{Cl}^{-}(P<0.01)$ after 1 st sampling in Blood. Figure 1. shows the difference between test and control group for 1 st and 2nd sampling in Blood and Urine. Gender difference confirmed for Urea $(P<0.05)$ variable after 2 nd sampling in Urine and for Urate $(P<0.01 / 0.05)$, Glu $(P<0.01 / 0.05)$ and $\mathrm{Ht}(P<0.01 / 0.05)$ after 1 st and 2 nd sampling and $\mathrm{MCHC}(\mathrm{P}<0.05)$ during 2nd sampling in Blood.

The amount of water intake, diseases, usage of drugs and profession type can lead to electrolyte misbalance resulting in quality and interpretation, further prognosis, diagnosis and patient follow-up [10, 11]. In this study, the percentage difference between genders exists for Urea (52.22\%) after 2 nd sampling in Urine. In Blood for Urate (1st:15.16\%; 2nd:14.5\%), Glu (1st:13.63\%; 2nd:8.7\%), Ht (1st and 2nd:7.23\%) 
during 1 st and 2nd sampling and $\mathrm{MCHC}(2.1 \%)$ during 2nd sampling. Males have higher values in comparing to females. Sex hormones affect gender differences [12-15]. Female sex hormones (Estrogen) regulate the activity of glucose and urate transporters (ABCG2 and SLC2A9), having different transporter expression (transcription, post-translational modification), localization and activity $[12,13]$. Male sex hormones (Testosterone) affect $\mathrm{MCHC}$ and $\mathrm{Ht}$ level through the increase of erythropoietin, reduction of ferritin and hepcidin [14]. Testosterone influence protein metabolism and the urea cycle [15].

Drinking more water improves kidney function and clearance of toxins by glomerular filtration, tubular secretion, and activation of various degradative metabolic pathways [17]. Results indicate that water intake influence Urine [FPD (86.5\%), K+ (81.7\%), Na+ (104.1\%), Cl- (97.37\%), Urea (75.34\%), Cr (116.45\%), Urat (89.65\%)] and Blood [K+ (9.5\%), $\mathrm{Cl}-(3.92 \%)]$ during 1 st sampling. There is a link between water intake and homeostatic mechanisms to maintain water balance and health outcomes. Urine osmolarity depends on cations, $\mathrm{Na}+, \mathrm{K}+, \mathrm{NH} 4+$, anions and Urea, whereas FPD enables estimation of urine osmolality $[18,19]$. Freezing point depression as a colligative property depends on the molality of the solute [20]. Renal $\mathrm{Cr}$ excretion level depends on the glomerular filtration rate, proximal tubular secretion and OCT-2 transporter [21, 22]. Higher water intake after 3. days causes a decrease of uric acid, upregulation of GLUT9 and URAT1 and down-regulation of ABCG2 and OAT1, while after 7 . days affect NPT1 down-regulation in hyperuricemia mice [23]. Urate level depends on transport proteins (URAT1 and GLUT9), uricase inactivation and possible change of the intestinal microbiota [23]. Production of concentrated Urine requires interactions among the nephron segments and vasculature in the kidney medulla [24]. Arginine vasopressin (AVP) is a key molecule in water homeostasis. Increase water intake, decrease AVP, reduce risk of renal and metabolic diseases and improve health outcome [24]. Vasopressin regulates urea transport acutely by increasing UT-A1 phosphorylation and the apical plasma-membrane accumulation of UT-A1 through two cAMP-dependent pathways [25]. Glut9 plays a major role in urate homeostasis by its dual role in urate handling in the kidney and uptake in the liver [26]. Small water intake can lead to dehydration, activation of the renin-angiotensin system (RAS) through angiotensin receptors and subsequent activation of signalling molecules, protein kinase $C$, reactive oxygen species, MAP kinase pathway mediated with angiotensin (27). Prolactin, aldosterone and antidiuretic hormone, influence water metabolism and electrolyte balance [28-37].

Results show higher concentration percentage increase in variables from Urine [FDP (68\%), $\mathrm{Na}+(62.96 \%)$, $\mathrm{K}+(21.88 \%), \mathrm{Cr}(65.2 \%)$, Urat (69.2\%), Urea (96.27\%)] in comparing to Blood [Urea (10.5\%), Urate (7.1\%), Glu (2.2\%), Ht (2.43\%), TR (3.9\%)] between 1st and 2nd sampling of 7th and 9th day of water intake. Studies indicate that daily water intake in healthy Japanese adults' decrease blood pressure, $\mathrm{Ht}$, Urine gravity and a rise in body temperature [38]. Lower and steady daily water intake increase $\mathrm{Cr}$, Cortisol, Urea, Uric acid, $\mathrm{Na}+, \mathrm{Hg}$; decrease CRP, and have no change in $\mathrm{Ht}$, active rennin, aldosterone and plasma osmolality [39-42].

Ex vivo cellular injury, disintegration, cellular granule release and protease activation causes alterations of cell release in vitro after sampling [1]. Hydration biomarkers in $24 \mathrm{~h}$ urine correlate with daily total fluid intake volume in sedentary adults in free-living conditions [43]. Literature findings follow the results of the 
study. Explain differences in concentration changes of healthy participants, due to water intake and sample sampling.

\section{Conclusions}

Information about the water regime during 7-9 days and gender in healthy participants positively impact further clinical studies on disease patients. Water intake changes Blood and Urine biomarker concentration. Advantage of the study is clinical reproducibility, applicability, fast and precise insight into physiological changes. Results can be a reference point for protocol standardization and quality control check. Lead the improvement of healthcare service. The disadvantage is the number of participants, absence of additional information (habits, demography and genetic analysis). Future work should emphasize disadvantages by comparing health/disease states to draw clinically applicable conclusions.

\section{List Of Abbreviations}

Arginine vasopressin (AVP), Chloride_Cl', Control_C, Creatinine_Cr, C reactive protein_CRP, Erythrocyte_ER, Female_F, Freezing point depression_FPD, Glucose_Glu, Hematocrit_Ht, Hemoglobine_Hg, Leucocyte_LE, Male_M, Mean Corpuscular Volume_MCV, Mean Corpuscular Hemoglobin_MCH, Mean Corpuscular Hemoglobin Concentration_MCHC, MPV_Mean Platelet Volume, Potassium_K+ ${ }^{+}$, Sodium_Na ${ }^{+}$, Test_T, Trombocyte_TR,

\section{Declarations}

\section{Acknowledgement}

I want to acknowledge the kind support of my CEEPUS-freemover mobility mentor from Slovenia, prof. Dr Damjana Drobne. Prof. Dr Damjana gave me the opportunity to work on this subject by ensuring me samples and place between research rooftop. She was kind to accept me to work with her on a project, to finalize my PhD thesis through CEEPUS freemover mobility network, and establish close collaboration between Universities. She introduced me closer to academia and scientific research. I also want to acknowledge my dear colleges from the Biotechnical faculty, M.Sc Alenka Malovrh, PhD student Neža Repar, and other team members of Bionanoteam who introduced me to practical scientific work in the laboratory and student mentoring. Prof. Dr Veronika Kralj Iglic, PI, gave me information about the project J5-7098 on which I worked through CEEPUS freemover mobility.

Moreover, I want to thank all the people who contributed to my education and my parents for the continuously given love and support. Thank you all for being a part of this lovely Snežana (Snow White) story, my life story. Life writes novels.

\section{Funding}


This research did not receive any specific grant from funding agencies in the public, commercial, or notfor-profit sectors. CEEPUS freemover PhD student program mobility and project J5-7098, "Assessment of blood parameters and extracellular vesicles for optimization of sport results" (PI Veronika Kralj-Iglic), enabled collaboration between the Biotechnical Faculty, University of Ljubljana, Slovenia and the University of Belgrade, Serbia with prof. Dr Damjana Drobne mentoring and accomplishment of the experimental part of the $\mathrm{PhD}$ thesis.

\section{Availability of data materials}

Data are available in Table 1 and 2.

\section{Ethical approval and consent to participate}

Experiments were performed according to ethical standards and with the written consent of the sample donors. Permission from the National Medical Ethics Committee, number 82/07/14, is given.

\section{Consent for publication}

"Not applicable"

\section{Competing interest}

The author, a PhD student, Snežana Jovičić, declare no competing interest.

\section{Author's contribution}

Author (Snežana Jovičić, PhD student at the Faculty of Biology, University of Belgrade, Serbia), originated data collection, analysis, interpretation and writing. The author made all the effort, accuracy, integrity and quality. Author approves the final version of the presented manuscript for submission. Author, confirms that this work is original and has not been published elsewhere, nor is it currently under consideration for publication elsewhere.

\section{References}

1. Kang HJ, Jeon SY, Park JS, Yun JY, Kil HN, Hong WK, Lee MH, Kim JW, Jeon JP, Han BG: Identification of clinical biomarkers for pre-analytical quality control of blood samples. Biopreserv Biobank. 2013, 11(2):94-100.1

2. Dolscheid-Pommerich RC, Klarmann-Schulz U, Conrad R, Stoffel-Wagner B, Zur B: Evaluation of the appropriate time period between sampling and analyzing for automated urinalysis. Biochem Med (Zagreb). 2016, 26(1):82-9.

3. Narayanan S: The preanalytic phase. An important component of laboratory medicine. Am J Clin Pathol. 2000, 113(3):429-52. 
4. Ramachandran VS: .Encyclopedia of Human Behaviour.2nd edition, ed. Asarian L, Gloy V, Geary N. Homeostasis. Reference module in Neuroscience and Behavioural psychology. London; Burlington, MA: Elsevier/Academic Press, 2012, 324-33.

5. Fink G: Stress: Concepts, Cognition, Emotions and Behaviour. Handbook of Stress Series, ed. McEven BS: Central role of the brain in stress and adaptation: Allostasis, Biological Embedding and Cumulative change. Vol. 1. Chap.5, Elsevier, 2016, 39-55.

6. Gonzalez-Dominguez R, Gonzalez-Dominguez A, Sayago A, Fernandez-Recamales A:

Recommendations and Best Practices for Standardizing the Pre-Analytical Processing of Blood and Urine Samples in Metabolomics. Metabolites. 2020, 10(6):229.

7. Yin P, Lehmann R, Xu G: Effects of pre-analytical processes on blood samples used in metabolomics studies. Anal Bioanal Chem. 2015, 407(17):4879-92.

8. Agrawal L, Engel KB, Greytak SR, Moore HM: Understanding preanalytical variables and their effects on clinical biomarkers of oncology and immunotherapy. Semin Cancer Biol. 2018, 52(Pt 2):26-38.

9. Dakappagari N, Zhang H, Stephen L, Amaravadi L, Khan MU: Recommendations for clinical biomarker specimen preservation and stability assessments. Bioanalysis. 2017, 9(8):643-53.

10. Puga AM, Lopez-Oliva S, Trives C, Partearroyo T, Varela-Moreiras G: Effects of Drugs and Excipients on Hydration Status. Nutrients, 2019, 11(3):669.

11. Liska D, Mah E, Brisbois T, Barrios PL, Baker LB, Spriet LL: Narrative Review of Hydration and Selected Health Outcomes in the General Population. Nutrients, 2019, 11(1):70.

12. Zhang Y, Howard BV, Cowan LD, Yeh J, Schaefer CF, Wild RA, Wang W, Lee ET: The effect of estrogen use on levels of glucose and insulin and the risk of type 2 diabetes in american Indian postmenopausal women: the strong heart study. Diabetes Care. 2002, 25(3):500-4.

13. Halperin Kuhns VL, Woodward OM: Sex Differences in Urate Handling. Int J Mol Sci. 2020, 21(12):4269.

14. Paller CJ, Shiels MS, Rohrmann S, Menke A, Rifai N, Nelson WG, Platz EA, Dobs AS: Association between sex steroid hormones and hematocrit in a nationally representative sample of men. $J$ Androl. 2012, 33(6):1332-41.

15. Lam T, Poljak A, McLean M, Bahl N, Ho KKY, Birzniece V: Testosterone prevents protein loss via the hepatic urea cycle in human. Eur J Endocrinol. 2017, 176(4):489-96.

16. Clark WF, Huang SH, Garg AX, Gallo K, House AA, Moist L, Weir MA, Sontrop JM: The Chronic Kidney Disease Water Intake Trial: Protocol of a Randomized Controlled Trial. Can J Kidney Health Dis. 2017, 4:2054358117725106.

17. Negoianu D, Goldfarb S. Just add water. J Am Soc Nephrol. 2008, 19(6):1041-3.

18. Youhanna S, Bankir L, Jungers P, Porteous D, Polasek O, Bochud M, Hayward C, Devuyst O: Validation of Surrogates of Urine Osmolality in Population Studies. Am J Nephrol, 2017, 46(1):26-36.

19. Perrier ET, Buendia-Jimenez I, Vecchio M, Armstrong LE, Tack I, Klein A: Twenty-four-hour urine osmolality as a physiological index of adequate water intake. Dis Markers, 2015, 2015:231063. 
20. Feher J. Quantitative Human Physiology. An introduction. In. Osmosis and Osmotic pressure. $2^{\text {nd }}$ Elsevier. USA: 2017:182-198.

21. Musso CG, Oreopoulos DG: Aging and Physiological Changes of the Kidneys Including Changes in Glomerular Filtration Rate. Nephron Physiol, 2011, 119(1):1-5.

22. Ciarimboli G, Lancaster CS, Schlatter E, Franke RM, Sprowl JA, Pavenstädt H, Massmann V, Guckel D, Mathijssen RH, Yang W, Pui CH, Relling MV, Herrmann E, Sparreboom A: Proximal tubular secretion of creatinine by organic cation transporter OCT2 in cancer patients. Clin Cancer Res, 2012, 18(4):11018.

23. Wen S, Wang D, Yu H, Liu M, Chen Q, Bao R, Liu L, Zhang Y, Wang T: The Time-Feature of Uric Acid Excretion in Hyperuricemia Mice Induced by Potassium Oxonate and Adenine. Int J Mol Sci, 2020, 21(15):5178.

24. Guelinckx I, Vecchio M, Perrier ET, Lemetais G: Fluid Intake and Vasopressin: Connecting the Dots. Ann Nutr Metab. 2016, 68(Suppl 2):6-11.

25. Sands JM, Blount MA, Klein JD: Regulation of renal urea transport by vasopressin. Trans Am Clin Climatol Assoc. 2011, 122:82-92.

26. Preitner F, Bonny O, Laverrière A, Rotman S, Firsov D, Da Costa A, Metref S, Thorens B.. Glut9 is a major regulator of urate homeostasis and its genetic inactivation induces hyperuricosuria and urate nephropathy. Proc Natl Acad Sci U S A. 2009, 106(36):15501-6.

27. Coble JP, Grobe JL, Johnson AK, Sigmund CD: Mechanisms of brain renin angiotensin systeminduced drinking and blood pressure: importance of the subfornical organ. Am J Physiol Regul Integr Comp Physiol. 2015, 308(4):R238-R249.

28. Alamer M: The Role of Prolactin in Thermoregulation and Water Balance During Heat Stress in Domestic Ruminants. Asian Journal of Animal and Veterinary Advances. 2011, 6(12):1153-69.

29. Kenyon CJ, Saccoccio NA, Morris DJ: Aldosterone effects on water and electrolyte metabolism. J Endocrinol. 1984, 100(1):93-100.

30. Andersson B, Leksell LG, Rundgren M: Regulation of water intake. Annu Rev Nutr. 1982, 2:73-89.

31. Burstyn PG: Sodium and water metabolism under the influence of prolactin, aldosterone, and antidiuretic hormone. J Physiol. 1978, 275:39-50.

32. Falconer IR, Rowe JM: Effect of prolactin on sodium and potassium concentrations in mammary alveolar tissue. Endocrinology. 1977, 101(1):181-6.

33. Kulczycki LL, Robertson MT: The sweat chloride concentration and prolactin activity in cystic fibrosis. Scand J Gastroenterol Suppl. 1988, 143:28-30.

34. Scott JH, Menouar MA, Dunn RJ: Physiology, Aldosterone. [Updated 2020 Jul 26]. In: StatPearls [Internet]. Treasure Island (FL): StatPearls Publishing; 2020 Jan-. Available from: https://www.ncbi.nlm.nih.gov/books/NBK470339/.

35. Work J, Galla JH, Booker BB, Schafer JA, Luke RG: Effect of ADH on chloride reabsorption in the loop of Henle of the Brattleboro rat. Am J Physiol. 1985, 249(5 Pt 2):F698-703. 
36. Lorenz JM. Chapter 3 - Potassium Metabolism. In: William Oh, Jean-Pierre Guignard, Stephen Baumgart, Richard A (editors). Polin,Nephrology and Fluid/Electrolyte Physiology: Neonatology Questions and Controversies,W.B. Saunders; 2008, 54-65.

37. Young DB, Pan YJ, Guyton AC: Control of extracellular sodium concentration by antidiuretic hormonethirst feedback mechanism. Am J Physiol, 1977, 232(5): R145-9.

38. Nakamura Y, Watanabe H, Tanaka A, Yasui M, Nishihira J, Murayama N: Effect of Increased Daily Water Intake and Hydration on Health in Japanese Adults. Nutrients, 2020, 12(4): 1191.

39. Hyun-Kyung K, Kim SH, Ryu JK: Changes in the Blood components caused by water intake. Korean J of Clinical and Laboratory Science, 2017, 49(3):227-32.

40. Perrier E, Vergne S, Klein A, Poupin M, Rondeau P, Le Bellego L, Armstrong LE, Lang F, Stookey J, Tack I: Hydration biomarkers in free-living adults with different levels of habitual fluid consumption. $\mathrm{Br} \mathrm{J}$ Nutr, 2013, 109(9): 1678-87.

41. Unal K: The effect of daily water intake on blood biochemical markers in healthy individuals. Turkish journal of Occupational/Environmental medicine and safety, 2017, 2:1(3):230-7.

42. Benozzi SF, Unger G, Campion A, Pennacchiotti GL: Fasting conditions: Influence of water intake on clinical chemistry analytes. Biochem Med (Zagreb), 2018, 28(1): 010702.

43. Perrier E, Rondeau P, Poupin M, Le Bellego L, Armstrong LE, Lang F, Stookey J, Tack I, Vergne S, Klein A: Relation between urinary hydration biomarkers and total fluid intake in healthy adults. Eur $J$ Clin Nutr. 2013;67(9):939-43.

\section{Figures}



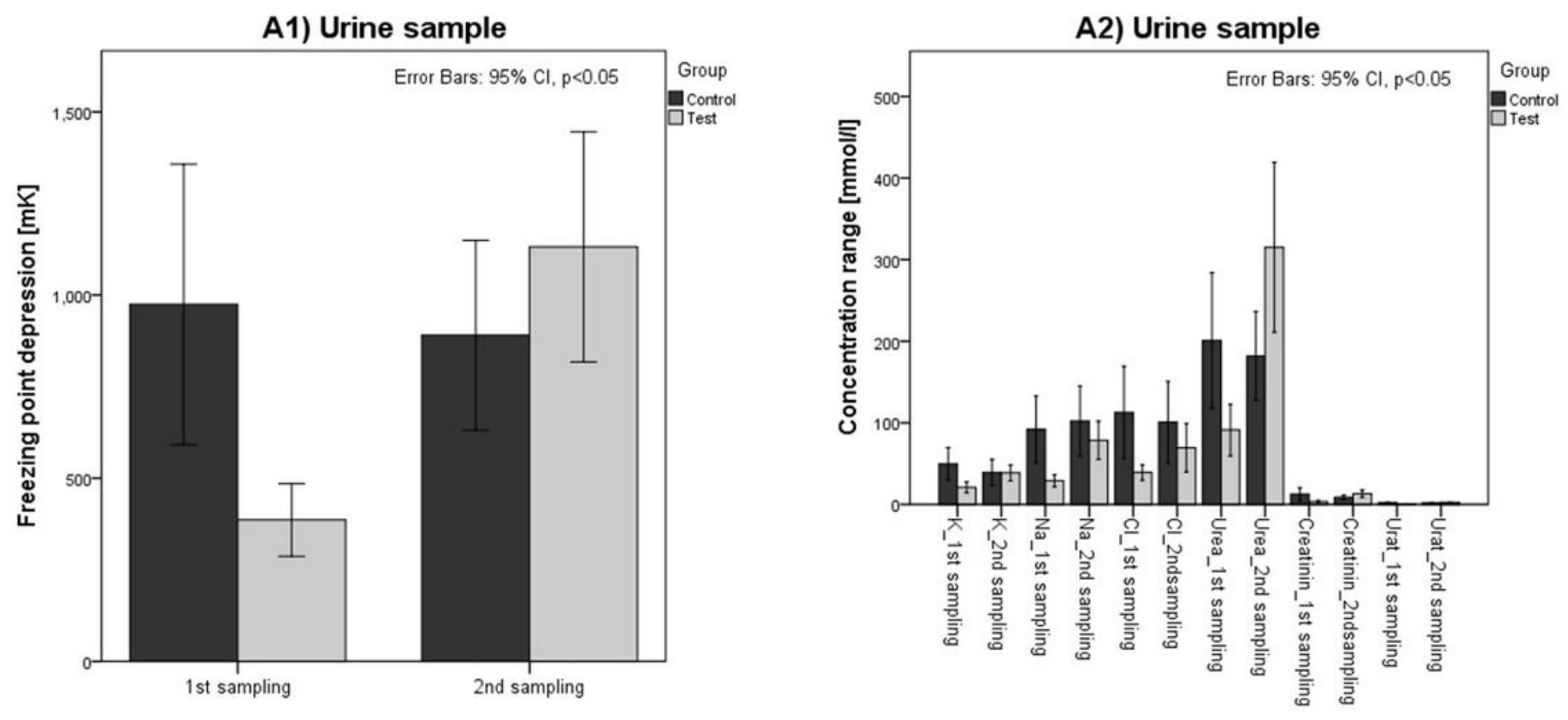

\section{B) Blood sample}

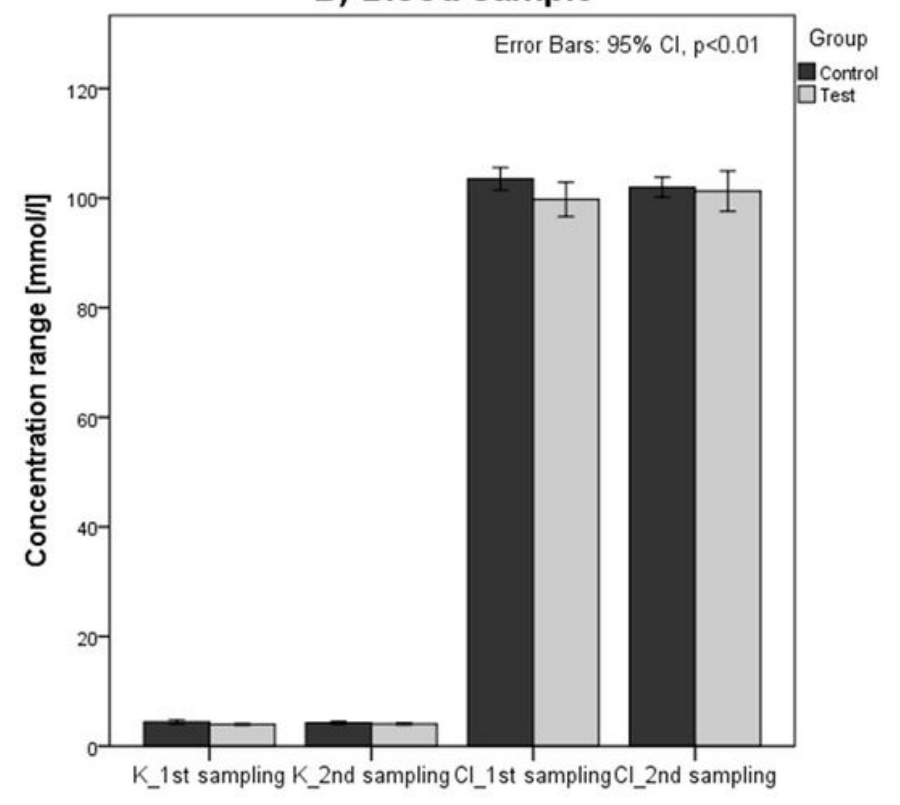

Figure 1

Differences between Test and Control group in Urine (A1, A2) and Blood (B) sample 